In the "Outlines of the History of Ethics for English Readers," Sidgwick has supplied a most useful guide to the study of the subject. In the "Principles of Political Economy" (Ist ed., I883; 2nd, I887) and in "The Scope and Method of Economic Science" (1885), there is a return to the older English thought, but the subject is treated with an acuteness and originality specially characteristic of Sidgwick's intellect, which have given to these works real value as contributions to economic science. The third book of the principles contains the "Art of Political Economy," which, together with "The Elements of Politics" (Ist ed., I891 ; 2nd, I897), shows the keen interest always felt by Sidgwick in political and social questions, and the practical sagacity with which he handles these problems. In politics, Sidgwick combined the freedom from prejudice of the Radical with the caution of the Conservative.

Perhaps the most important practical work with which the name of Sidgwick has been associated is in connection with the higher education of women. He was the virtual founder of Newnham College, through the scheme of lectures for women which he initiated in 1869 , and the house of residence which he started and persuaded Miss Clough to take charge of in $187 \mathrm{I}$. In 1880 , Mrs. Sidgwick having consented to become vice-principal of the second Hall of the College just opened, they both came to live there for two years; and when, after Miss Clough's death in I892, Mrs. Sidgwick became principal of the College, they made it their permanent home.

In 1882 Sidgwick accepted the presidency of the newly formed Society for Psychical Research, in the subject-matter of which he had been interested for many years. The spirit which has characterised the proceed. ings of the Society, and the success which it has achieved, have been largely due to the sobriety and wisdom of Sidgwick's constant counsel and control.

\section{PROF. JAMES EDWARD KEELER.}

$T \mathrm{HE}$ sudden death of Prof. James E. Keeler, director of the Lick Observatory, which occurred at San Francisco on August 12, removes one who stood at the very forefront of astrophysical research.

James Edward Keeler was born at La Salle, Illinois, on September 8, 1857. His qualifications for scientific work clearly showed themselves at the Johns Hopkins University, where he took an undergraduate course, and served as assistant to Prof. Hastings, with whom he observed the total sclar eclipse of 1878 in Colorado.

Shortly after this he was appointed assistant at the Allegheny Observatory, where he had an important part in the long series of bolometric investigations carried on by Prof. Langley, then director of the Observatory. In July $188 \mathrm{r}$ he was a member of Prof. Langley's wellknown expedition to Mount Whitney, in Southern California, where an extensive region in the extreme infrared of the solar spectrum was discovered with the bolometer. Later he studied for two years in Berlin and Heidelberg under Helmholtz and Quincke, and returned to the Allegheny Observatory, where he remained until appointed a member of the staff of the Lick Observatory. His work on Mount Hamilton commenced in $\mathrm{r} 885$, and for some time he was the only astronomer at the Observatory, which was still in process of construction. In May I89 I he was elected professor of astrophysics in the Western University of Pennsylvania and director of the Allegheny Observatory.

Keeler's work at the Lick Observatory was continued in a most effective manner with the modest instrumental resources at Allegheny. With a full understanding of the art of making the most of his means, he took up photo-

1 Abridged from an obituary notice contributed to Science of September 7 by Prof. George E. Hale.

NO. I6I2, VOL. 62] graphy for the first time, made himself thoroughly familiar with photographic processes, and then, with the aid of a spectrograph whose general design has been followed in the construction of the great modern spectrographs at Mt. Hamilton, Potsdam, Pulkowa and Williams Bay, he obtained the photographs of the spectra of red stars which excited so much interest at the dedication of the Yerkes Observatory. He also made an admirable series of drawings of Mars, which was published in the Memoirs of the Royal Astronomical Society.

In the spring of 1898 Keeler had practically decided to accept a position on the staff of the Yerkes Observatory, and would have done so had he not just then been appointed director of the Lick Observatory. His recent work on Mt. Hamilton has not been confined to the direction of the affairs of a great observatory. The remarkable success of his experiments with the Crossley reflector, of which a full account is fortunately preserved in the June number of the Astrophysical Journal, has impressed every one who has seen the wonderful photographs of nebulæe and star clusters made with this instrument.

Of Keeler's other contributions to science two in particular deserve present mention : his determination with the Lick telescope of the motion in the line of sight of the planetary nebulæ, and his demonstration of the meteoric constitution of Saturn's rings. The memoir which describes the first of these investigations already ranks as a classic of astrophysical literature; while the spectroscopic demonstration of the meteoric constitution of Saturn's rings is perhaps the most striking of the many effective applications which have been made of Doppler's fruitful principle.

Much more might be said of Keeler's work, but this should suffice to indicate its lasting value. It is a satisfaction to add that its merit has been widely appreciated, as has recently been evidenced by the award of the Uraper and Rumford medals. He was president of the Astronomical Society of the Pacific and a councillor of the Astronomical and Astrophysical Society of America. He was elected an Associate of the Royal Astronomical Society in 1898 and a member of the National Academy of Sciences at its last meeting. His kindly and genial manner, combined with unusual tact and rare judgment, drew to him many friends, who will long mourn his loss.

\section{NOTES}

THE annual meeting of the Iron and Steel Institute was opened at Paris on Tuesday with an address by the president, Sir W. Roberts-Austen, K.C.B., F.R.S. It was announced that Mr. Andrew Carnegie has offered to the Institute the sum of $6500 l$. for the purpose of founding a medal and scholarship to be awarded for any piece of work that may be done in any works or University, and to be open to either sex.

IT is stated by the Paris correspondent of the Times that M. Yersin, to whom the Academy of Moral Sciences recently awarded a prize of 15,000 francs for philanthropic acts, has devoted the sum to his anti-plague serum establishment at Nha-trang.

THE British Medical Journal announces that the prize of 4000 marks voted by the Berlin Congress of Tuberculosis for the best popular work on tuberculosis as a social scourge, and the means of preventing its ravages, has been awarded to Dr. S. A. Knopf, of New York. The work will be published by the German Central Committee.

A TABLE of standard sizes of conductors for electric supply mains has been drawn up by the Cable Makers' Association and sent to electrical engineers. The table shows the nominal 